\title{
Impacts of free market and US foreign policy on Colombian and Latin American revolution ${ }^{*}$
}

\author{
Noam Chomsky ${ }^{1}$ \\ MIT - Massachusetts Institute of Technology (United States)
}

Recibido: junio 2 de 2015 - Revisado: junio 3 de 2015 - Aceptado: junio 4 de 2015

Referencia formato APA: Chomsky, N. (2015). Impacts of free market and US foreign policy on Colombian and Latin American revolution.

Revista Científica Guillermo de Ockham, 13(1), 21-25.

\section{Abstract}

After several coups assisted by US agencies since the fifties in Latin America, and deep economic crises in the eighties and the nineties in South America explained by "the rule of markets" enforced by multilateral organizations, the US leadership in the Americas has been lost, and democratic countries have turned against neoliberalism with wide popular support inside a new "South American revolution" with important projects of integration. Colombia has become the capital in South America for US leadership in economics and politics, and the only country that still has guerrillas, paramilitary armies, and internal conflict. What has been the role of the US in Colombian conflict? What is in stake with the new peace process in Colombia? How this process will affect the US leadership in Latin America? These are some questions that will be reviewed by Noam Chomsky, one of the most influential thinkers of our times.

Keywords: North American Free Trade Agreement (NAFTA), narcotrafickers, guerrillas (FARC), paramilitary armies, peace process, Colombia

Colombia is a wonderful and tragic country. It is rich in resources, has remarkable biological diversity and every possibility to become a flourishing and productive society, but it has been plagued with extraordinary levels of violence and terror. At last, there seem to be signs of internal reconciliation, notably the government-FARC negotiations proceeding in Havana. One can only hope that the prospects will not be sacrificed, that bitter hatreds and fears, however understandable, can be brought under control, and that an atmosphere of tolerance and mutual respect will be cultivated despite the shocking recent history of depravity and destruction.

I have had a chance to visit Colombia several times. My first trip was 15 years ago, with an Amnesty International delegation, opening the AI campaign to protect human rights defenders. The year-long campaign began in Colombia for good reasons, in the light of Colombia's shocking record of violence, not sparing human rights activists. I met marvellous people, like Fr. Javier Giraldo, whose courageous work in defense and human rights almost defies description. He is also the author of the indispensable book Colombia: Genocidal Democracy, and I was fortunate to meet other priests and human rights activists working to create zones free of terror - at the time, overwhelmingly terror by paramilitaries and the military, closely linked. We were also able to meet the president of the Colombian Permanent Committee for Human Rights, the distinguished diplomat Alfredo Vázquez Carrizosa, at his heavily guarded home in Bogota. I will return to his account of the roots of contemporary terror.

I made several later trips, mainly to Cauca, together with Colombian human rights activists, to gather evidence and testimonies of victims. On one occasion we were able to get only as far as Popayan. Violence in the region was too extreme for us to travel into the countryside, but activists there were able to bring to Popayan people from surrounding communities who provided shocking reports of terror and the devastating effects of chemical

* Text given at the Third Colombian Conference at MIT-Harvard-BU. Colombia: Building Peace. Cambridge, MA, April 23-25, 2015.

1. Institute Professor \& Professor of Linguistics (Emeritus). MIT - Massachusetts Institute of Technology. E-mail: chomsky@mit.edu 
warfare (politely called "fumigation"). Later, I travelled to the remote village of Santa Rita in La Vega, far from the Pan-American highway on a virtually impassable road. The first effort had to be cancelled because of violence in the region, but a few months later I was able to go there with Colombian friends, with the crucial assistance of the Ombudsman's office. Not far from the village we passed an open area with several dozen simple crosses, the graves of the victims of a paramilitary attack on a bus. We attended a meeting of villagers where they discussed quite sophisticated projects to try to protect their water supply from destruction by international mining corporations. The visit was of deep personal significance to me. Villagers were dedicating a virgin forest on a nearby mountain to my late wife, placing a plaque high up on the mountain La Carolina. It was an extremely moving experience. I have never experienced anything like the simple compassion and sympathy of the campesinos and indigenous people in this remote and materially poor village - materially poor, not morally and spiritually.

These and similar experiences are not in themselves remarkable. They illustrate the lives of people plagued with multiple curses: paramilitary and military terror, development projects that destroy their lives and communities, a US-inspired "drug war" that is carefully targeted to avoid major narcotraffickers within the governmentparamilitary system, creating one of the largest displaced populations in the world and freeing the devastated lands for exploitation by mining companies and other projects benefiting the rich elite. A major achievement of Clinton's Plan Colombia, which radically militarized the conflict with the guerrillas, has been to turn FARC from a peasantbased movement with some kinds of social programs to just another terrorist force preying on the campesinos, indigenous, and Afro-Colombians.

Colombia's extremely violent history dates back a long time. A new era opened in early 1960s, when President John F. Kennedy effectively shifted the mission of the Latin American military from "hemispheric defense" - a holdover from World War II - to "internal security," which means, in reality, war against the population. The effects were described by Charles Maechling, who led counterinsurgency and internal defense planning under Kennedy and Lyndon Johnson. Kennedy's 1962 decision, he wrote, shifted US policy from toleration "of the rapacity and cruelty of the Latin American military" to "direct complicity" in their crimes, to US support for "the methods of Heinrich Himmler's extermination squads."
The effects in Colombia were immediate. Also in 1962, Kennedy sent a Special Forces mission to Colombia led by General William Yarborough, which recommended "paramilitary, sabotage and/or terrorist activities against known communist proponents," to be employed as soon as "we have such an apparatus" in place. Note the pronoun "we." This was a secret internal document, so there was no need to prevaricate.

The phrase "communist proponents" has broad application in US counterinsurgency doctrine. Its meaning was spelled out Vásquez Carrizosa. Echoing Maechling, he explained that the Kennedy administration "took great pains to transform our regular armies into counterinsurgency brigades, accepting the new strategy of the death squads," ushering in "what is known in Latin America as the National Security Doctrine,...not defense against an external enemy, but a way to make the military establishment the masters of the game [with] the right to combat the internal enemy...: it is the right to fight and to exterminate social workers, trade unionists, men and women who are not supportive of the establishment, and who are assumed to be communist extremists. And this could mean anyone, including human rights activists such as myself" - which is why he was under heavy guard when we visited him.

Events followed what Maechling and Vasquez Carrizosa describe. The National Security Doctrine was imposed at once in Brazil with a military coup in 1964, shortly after the assassination of President Kennedy, whose administration had helped prepare the ground. The coup established the first neo-Nazi terror and torture state, soon followed by many others - Chile, Uruguay, Argentina, maybe the worst of them all and a particular favorite of Henry Kissinger and the Reaganites. The plague reached Central America in the Reagan years. The basic problem the US faced throughout was formulated clearly by Kissinger, when he was laboring to destroy Chilean democracy and install the vicious Pinochet dictatorship: the Allende regime, he said, is a "virus" that might "spread contagion," the threat that socialist democracy might be established by parliamentary means, a disease that might reach as far as southern Europe, it was feared.

The solution in such cases is to destroy the virus and inoculate potential victims with murderous dictatorships, a leading theme of imperial history, given various names: the domino may fall, one rotten apple may spoil the barrel, "the idea of taking matters into your own hands" might spread, and other supreme dangers to order and stability. 
The destruction of democracy in Brazil, the most important state in Latin America, was welcomed enthusiastically in Washington as a "democratic rebellion," "a great victory for the free world," which prevented a "total loss to West of all South American Republics" -- and should, incidentally, "create a greatly improved climate for private investments." It was "the single most decisive victory of freedom in the mid-twentieth century," US Ambassador to Brazil Lincoln Gordon held, describing it as "one of the major turning points in world history" in this period.

Gordon's reference to turning points in world history is quite appropriate. We make a serious error when we limit attention to only one region, forgetting that US is a global imperial power so that, quite commonly, policies applied in one region are mirrored elsewhere. One of the ideological traps that we should be careful to avoid is localizing the problems of a region to that specific region-Vietnam, Cuba, Iran, and others. Ignored is that the problems to a large extent derive from the imperial hegemony itself, a crucial fact deflected in approved ideology, and illustrated very clearly in the case we are considering.

A year after the imposition of the military dictatorship in Brazil, a US-backed military coup in Indonesia led to the massacre of hundreds of thousands of victims, mostly landless peasants, destroying the major mass political party, the Communist Party, basically a party of the poor, according to the leading Australian Indonesia scholar Harold Crouch. The coup instituted a vicious and murderous dictatorship under General Suharto. The events were well understood in the West. The New York Times described them as a "staggering mass slaughter" that was a "gleam of light in Asia." Time magazine celebrated "The West's best news for years in Asia" under the heading "Vengeance with a Smile," devoting a full eleven pages to the "boiling bloodbath" that it welcomed, along with commentary in the West quite generally. Defense Secretary Robert McNamara boasted to the President that US military assistance to the Indonesian army had "encouraged it" to carry out the staggering mass slaughter "when the opportunity was presented," crediting particularly the training of Indonesian officers in American universities.

The general euphoria was understandable. Indonesia's rich resources were opened to exploitation by western corporations, and the slaughter ended a threat of (limited) democracy in Indonesia, which greatly concerned Washington. It also quelled fears that the most important country of Southeast Asia might be infected by the virus of independent development in Vietnam. Years later, McGeorge Bundy, National Security Adviser under
Kennedy and Johnson, reflected that it might have been wise to end the Vietnam war right at that time. Vietnam had already been severely damaged and was not going to be a model for anyone, and the threat of contagion was ended when Indonesia was safeguarded from infection.

The gleam of light in Indonesia also eliminated one of the pillars of the despised Non-aligned movement. A second was eliminated two years later when Israel destroyed Nasser's army in 1967, firmly establishing the U.S.-Israel alliance that has persisted since. The Nonaligned movement never recovered. By now $80 \%$ of the world's population is largely excluded from what is called the "international community." There are many striking illustrations. To mention one, of great contemporary significance, the Non-aligned movement has vigorously supported Iran's right, as a signer of the Nonproliferation Treaty, to pursue its nuclear programs, as the Treaty allows. The "international community," in contrast, openly threatens war if Iran persists.

As I mentioned, the plague reached Central America in the 1980s under Reagan's "war on terror," which instantly turned into a huge terrorist war carried out by Washington and its murderous clients. Hundreds of thousands were killed, with every imaginable form of torture and horror. The worst atrocities were in Guatemala, which has remained a horror chamber, with constant US support, since Washington's overthrow of Guatemala's promising experiment in democracy and human rights in 1954. In the early 1980s, Guatemalan atrocities reached truly genocidal levels in the Mayan regions under the leadership of Reagan's personal favorite, Rios Montt. Reagan was prevented from joining directly in the slaughter by congressional restrictions, so he had to mobilize a terrorist network to do the job. Argentine neo-Nazis, the worst killers in Latin America, were among those assigned the task, but after the unfortunate overthrow of the dictatorship they were no longer available, and the task was undertaken by Israel, always eager to apply its expertise in violence and repression at the service of the global master. Because of these restrictions on support for Guatemala, El Salvador became the leading recipient of US aid, and had the worst human rights record apart from Guatemala - a standard correlation, well-established in scholarship.

The leading US academic specialist on human rights in Latin America, Lars Schoultz, found in a 1981 study that US aid "has tended to flow disproportionately to Latin American governments which torture their citizens,... to the hemisphere's relatively egregious violators of fundamental human rights" (Schoultz, 1981a). That 
includes military aid, is independent of need, and runs through the Carter period. In another academic study, Latin Americanist Martha Huggins reviewed data for Latin America suggesting that "the more foreign police aid given [by the US], the more brutal and less democratic the police institutions and their governments become" (Huggins, 1998, p. 6).

Economist Edward Herman found the same correlation between US military aid and state terror worldwide, but also carried out another study that gave a plausible explanation. US aid, he found, correlated closely with improvement in the climate for business operations, as one would expect. And in US dependencies it turns out with fair regularity that the climate for profitable investment and other business operations is improved by killing union activists, torture and murder of peasants, assassination of priests and human rights activists, and so on. There is, then, a secondary correlation between US aid and egregious human rights violations.

The basic principles of state terror are explained by Schoultz (1981b) in his standard scholarly work on US foreign policy and human rights in Latin America. Referring to the "national security states" backed by the US from the early 1960s, Schoultz writes that the goal of state terror was "to destroy permanently a perceived threat to the existing structure of socioeconomic privilege by eliminating the political participation of the numerical majority..., [the] popular classes."

The pattern has been followed since. The peace accords in El Salvador in 1992 sharply reduced state crimes, so the country was dropped from its position as leading recipient of US military aid. It was replaced by Colombia, which, since then, has led the hemisphere in human rights violations and, correspondingly, has been by far the leading recipient of US military aid in Latin America.

Excluding Israel-Egypt, which are a separate category, the leading recipient of US military aid worldwide in the 1990s was Turkey, which was at the time conducting a horrific attack on its Kurdish population, leaving tens of thousands killed, thousands of towns and villages destroyed, and probably millions driven from their homes. Eighty percent of the arms came from Washington, the flow escalating as atrocities increased. In the single year 1997, Clinton sent more military aid to Turkey than in the entire Cold War period combined up to the onset of the counterinsurgency campaign. By 1999, Turkey had crushed Kurdish resistance, so Colombia replaced Turkey as the world leader in military aid, meanwhile sharply increasing its leadership role in human rights violations.
It has long been known that Colombia was the world champion in murder of union activists and other state crimes, often with state collusion with paramilitaries and death squads, but the actual extent of these crimes has only recently been recognized.

Earlier estimates of civilians killed by paramilitaries were about 30,000. But a few years ago, Colombia's Prosecutor-General revealed that it is investigating 150,000 extrajudicial killings by the paramilitary groups from the late ' 80 's to the present. That places Colombia well beyond even the Argentine neo-Nazi junta and the Pinochet dictatorship. Very close collaboration in a government-paramilitary-narcotrafficking alliance has also been revealed. A large part of Congress is under criminal investigation for paramilitary ties, and dozens have been convicted.

Colombia also has the hemispheric championship for displaced persons, by now over 4 million, one of the world leaders. While US aid mounts, many Colombians decline deeper into poverty. A 2010 report in the Washington Post, while noting that Colombia is "Washington's closest ally on the continent" and of course by far the leading aid recipient, found that $43 \%$ of its population live in poverty and 23\% in "extreme poverty." Colombia is, furthermore, "the only major country in Latin America in which the gap between the rich and poor has increased in recent years, according to a report by the UN Economic Commission on Latin America."

This is happening in a country with very rich resources and no external threats.

A study by the brave Colombian journalist Claudia López and a team of Colombian scholars, which revealed these facts, goes beyond in showing that the criminal conspiracy of government-paramilitaries-narcotrafickers has an ambitious plan to "refound the nation" - the title of their study -- to legalize the enormous wealth and power they had amassed during years of paramilitary expansion and create a new and even more grotesque Colombia.

President Obama reached a so-called "free trade agreement" to solidify the US relationship with its Colombian ally, by now one of the few allies in the hemisphere as a result of the remarkable changes in the hemisphere in the past ten-fifteen years. The agreement was strongly opposed by US unions and supporters of labor rights, considering Colombias awful record. That was supposed to be addressed by labor rights conditions, but they appear to have been completely ignored. The situation is reviewed in a recent study by the Escuela Nacional Sindical. The 
report shows that almost nothing has changed. An AFL$\mathrm{CIO}$ summary observes that the report "categorically assigns a failing grade in almost every measure included in the agreement."

A dramatic illustration is given by a Human Rights Watch study a year ago on the port town of Buenaventura, which was supposed to be "a model city for the glories of free trade," labor lawyer and activist Dan Kovalik comments, reviewing the document, which found (in its words) that "entire neighborhoods were dominated by powerful paramilitary successor groups... who restrict residents' movements, recruit their children, extort businesses, and routinely engage in horrific acts of violence against anyone who defies their will." These include perhaps hundreds of "disappearances," dismembering victims and dumping their body parts, so called "chopup houses' - where the groups slaughter their victims," often while they are still alive. The large majority are Afro-Colombians. The police and military do nothing, or even cooperate with the paramilitaries. Virtually no one is prosecuted. Tens of thousands have been forcibly displaced, more than any other municipality in Colombia.

Kovalik, who is a close and careful observer of Colombia, adds that "the violence in Buenaventura is largely being spurred on by paramilitary groups fighting over control of the lucrative ports which were built to accommodate the increased trade brought about by the Free Trade Agreement," one of its great achievements.

That raises a problem about part of the topic I was asked to talk about: "Impacts of free market policies." I assume what is meant is the so-called "free trade agreements," like NAFTA and others, or the massive TPP that is now under negotiation, in secret as usual - though it is not secret from the corporate lobbyists and lawyers who are drawing up the details, only from the general population, which is not supposed to know about them.

These agreements are curious creatures. Take NAFTA, the North American Free Trade Agreement, a model for others. The only accurate words in its title are "North American." It is not an agreement, at least if people are part of their country. In the US and Canada, polls showed majority opposition (and the same appeared to be true in Mexico). It is not about "free trade." On the contrary, there are quite extreme protectionist elements, like unprecedented protection of intellectual property. Much of the content is not even about trade; rather, about investor rights of an extreme form. The same seems to be true of the TPP, to the extent that we have information about it.

The "agreements" certainly have effects. As predicted, NAFTA has undermined Mexican agriculture. Mexican campesinos may be quite productive, but they cannot compete with US agribusiness, which is, furthermore, heavily subsidized in our free market economy. One result is a change in the flow of undocumented immigrants. In the past, there was a fairly regular flow up and back related to temporary agricultural employment in the US. Now, undocumented immigrants are coming from traditional corn-producing areas. There are many similar effects. As for the general economic impact, a good case can be made that NAFTA managed to harm working people in all of the countries involved. Since NAFTA, Mexico has had about the lowest growth rate in Latin America. Studies undertaken under NAFTA rules show that in the US, NAFTA contributed substantially to undermining labor organizing, with employer threats to transfer operations to Mexico if a union were formed. That is illegal, but employer violations are rarely prosecuted, and if they are, penalties are slight. There are doubtless some gains, for example, for US manufacturing corporations, which can send parts to Mexico for assembly and then back to the US for sale. That is called "trade" in both directions, though these are interactions within a command economy, a corporation.

Many illusions about "free trade" and "free markets" have to be carefully dismantled before we discuss the impact of policies that claim to be based on these principles - which, rather generally over the years, have been reshaped to protect the rich and powerful from the ravages of markets, while leaving the more vulnerable free to suffer their harmful effects.

\section{References}

Huggins, M. (1998). Political Policing: The United States and Latin America. Durham: Duke University Press.

Schoultz, L. (1981a). U. S. Foreign Policy and Human Rights Violations in Latin America: A Comparative Analysis of Foreign Aid Distributions. Comparative Politics, 13(2), 149-170.

Schoultz, L. (1981b). Human rights and United States policy toward Latin America. Princeton, NJ: Princeton University Press. 